\title{
Abbreviations and textual explanations
}

\section{Harvey}

There is no modern edition that contains all of Harvey's works.

Harvey, Works, ed. Grosart

Works of Gabriel Harvey, ed. Alexander Grosart, 3 vols, Huth Library (London; Hazell, Watson \& Viney, Ltd, 1884-85). This poorly annotated edition only selectively discusses the Latin works, but at present is the most comprehensive edition.

Familiar Letters

Three Proper and wittie, familiar Letters: lately passed betwene two Universitie men: touching the Earthquake in Aprill last, and our English refourmed Versifying. With the Preface of a wellwiller to them both. Two Other very commendable Letters of the same mens writing: both touching the foresaid Artificiall Versifying, and certain other Particulars: More lately delivered unto the Printer (London: H. Bynnneman, 1580). RB 69544. The Huntington Library, San Marino, CA. EEBO reproduces this text. This copy is missing F2-F3.

Foure Letters

Foure Letters, and certaine sonnets; especially touching Robert Greene, and other parties by him abused (London: John Wolfe, 1592). RB 61305. The Huntington Library, San Marino, CA.

Gratulationes Valdinenses

Gabrielis Harueij Gratulationum Valdinensium Libri Quatuor (Londini: Henrici Binnemani, 1578). RB 59268. The Huntington Library, San Marino, CA. 
Letter-Book

The Letter-Book of Gabriel Harvey, A.D. 1573-1580, edited from the original ms. Sloane 93 in the British Library, ed. Edward John Long Scott, Camden Society New Series, 33 (Westminster: Nichols and Sons, 1884). Text cited throughout this study. Scott's edition is a worthy transcription of Sloane 93, but he does simplify cross-outs and cross-overs.

Marginalia

Gabriel Harvey's Marginalia, collected and edited by G.C. Moore Smith (Stratford-upon-Avon: Shakespeare Head Press, 1913).

\section{Progresses}

This new edition of John Nichols's The Progresses and Public Processions of Queen Elizabeth I: A New Edition of the Early Modern Sources, ed. Elizabeth Goldring, Faith Eales, Elizabeth Clarke, and Jayne Elisabeth Archer, 5 vols (Oxford: Oxford University Press, 2014) includes a complete translation as well as annotated text of Gratulationes Valdinenses. The Latin text is reprinted from RB 59268 at the Huntington Library, San Marino, CA, which was used in preparing this study. I continue to use my translations, but, for the reader's convenience, I cite the pagination of Progresses for Gratulationes Valdinenses.

\section{Smithus}

Gabrielis Harueii Valdinatis: Smithus; vel Musarum Lachrymae. (Londini: Henrici Binnemani, 1578). RB 35263. The Huntington Library, San Marino, CA.

Stern, Harvey

Stern, Virginia, Gabriel Harvey: His Life, Marginalia, and Library (Oxford: Clarendon Press, 1979).

\section{Nashe}

Nashe, Works

The Works of Thomas Nashe, ed. Ronald B. McKerrow and corrected and supplemented by F.P. Wilson (Oxford: Blackwell, 1958). All citations are from this edition.

\section{ODNB}

Oxford Dictionary of National Biography, ed. H.C.G. Matthew and Brian Harrison, 60 vols (Oxford, 2004). I have updated my citations from the 2004 printed edition to the 2008 version cited online as per September 2018. 


\section{Sidney}

Sidney, Correspondence

Sidney, Sir Philip. The Correspondence of Sir Philip Sidney, ed. Roger Kuin, 2 vols (Oxford: Oxford University Press, 2012).

Sidney, Life

Duncan-Jones, Katherine, Sir Philip Sidney, Courtier Poet (New Haven: Yale University Press, 1991).

Sidney, Miscellaneous Prose

Miscellaneous Prose of Sir Philip Sidney, ed. Katherine Duncan-Jones and Jan Van Dorsten (Oxford: Clarendon Press, 1973).

\section{Spenser}

Grosart, Life

The Complete Works of Verse and Prose of Edmund Spenser, edited with a New Life, ed. Rev. Alexander Grosart, 9 vols (London and Aylesbury: Hazell, Watson, and Viney, Ltd, 1882-84). Volume 1 contains Grosart's biography.

Hadfield, Life

Hadfield, Andrew, Edmund Spenser, A Life (Oxford: Oxford University Press, 2012). Replaces Judson as the standard biography for Spenser's life. Judson, Life

Judson, Alexander Corbin. The Life of Edmund Spenser (Baltimore: Johns Hopkins University Press, 1945).

Knowles, HMC

Fourth Report of the Royal Commission of Historical Manuscripts, ed. R.B. Knowles, (London: George Edward Eyre and William Spottiswoode, 1874).

Nowell Account Book

Manchester, Chetham's Library, MS A.6.50. 'Accounts of the Executors of Robert Nowell', Attorney of the Queen's Court of Wards.

Spenser Encyclopedia

Spenser Encyclopedia, ed. A.C. Hamilton. General Editor; Donald Cheney, Senior Co-Editor; W.F. Blissett, Co-Editor; David A. Richardson, Managing Editor; William W. Barker, Research Editor (Toronto: Toronto University Press, 1990).

Spenser, Faerie Queene

The Faerie Queene, ed. A.C. Hamilton. Text edited by Hiroshi Yamashita and Toshiyuki Suzuki (London: Longman, 2001). 
Spenser, Shorter Poems, ed. McCabe

The Shorter Poems, ed. Richard A. McCabe (London: Penguin Books, 1999). This excellent and painstaking edition is used throughout to cite Spenser's shorter works.

Spenser, View

W.L. Renwick, A View of the Present State of Ireland (1934; Oxford: Clarendon Press, 1979). This widely available text is used for citations, but I also reference the Spenser Variorum edition. There is no authoritative edition of the View because five new manuscripts were discovered after the preparation of Spenser's Prose Works, vol. 10, ed. Rudolf Gottfried, in Works of Edmund Spenser: A Variorum Edition, ed. Edwin Greenlaw, Charles Grosvenor Osgood, Frederick Morgan Padelford, Ray Heffner, 11 vols (Baltimore: Johns Hopkins University Press, 1932-45).

Townley Hall MSS, ed. Grosart

The Townley Hall MSS. The Spending of the Money of Robert Nowell of Reade Hall, Lancashire: Brother of Dean Alexander Nowell. 1568-1580, ed. Alexander Grosart (Manchester: Charles E. Simms, 1877). A transcription of 'Accounts of the Executors of Robert Nowell' Manchester, Chetham's Library, MS A.6.50. 